\title{
Impaired leukocyte influx in cervix of postterm women not responding to prostaglandin priming Lena Sahlin*1, Ylva Stjernholm-Vladic ${ }^{2}$, Nathalie Roos ${ }^{2}$, Britt Masironi ${ }^{1}$ and Gunvor Ekman-Ordeberg ${ }^{2}$
}

Address: ${ }^{1}$ Division for Reproductive Endocrinology, Q2:08, Karolinska University Hospital - Solna, Karolinska Institutet, Stockholm, Sweden and 2Division of Obstetrics and Gynecology, H2:01, Department of Woman and Child Health, Karolinska University Hospital - Solna, Karolinska Institutet, Stockholm, Sweden

Email: Lena Sahlin* - Lena.Sahlin@ki.se; Ylva Stjernholm-Vladic - ylva.vladic-stjernholm@karolinska.se;

Nathalie Roos - nathalie.roos@karolinska.se; Britt Masironi - Britt.Masironi@ki.se; Gunvor Ekman-Ordeberg - Gunvor.Ekman-Ordeberg@ki.se

* Corresponding author

Published: 2 September 2008

Reproductive Biology and Endocrinology 2008, 6:36 doi:10.1/86/1477-7827-6-36

This article is available from: http://www.rbej.com/content/6/1/36

(C) 2008 Sahlin et al; licensee BioMed Central Ltd.

This is an Open Access article distributed under the terms of the Creative Commons Attribution License (http://creativecommons.org/licenses/by/2.0), which permits unrestricted use, distribution, and reproduction in any medium, provided the original work is properly cited.
Received: 30 June 2008

Accepted: 2 September 2008

\begin{abstract}
Background: Prolonged pregnancies are associated with increased rate of maternal and fetal complications. Post term women could be divided into at least two subgroups, one where parturition is possible to induce by prostaglandins and one where it is not. Our aim was to study parameters in cervical biopsies in women with spontaneous delivery at term (controls) and compare to those that are successfully induced post term (responders), and those that are not induced (non-responders), by local prostaglandin treatment.
\end{abstract}

Methods: Stromal parameters examined in this study were the accumulation of leukocytes (CD45, CD68), mRNAs and/or proteins for the extracellular matrix degrading enzymes (matrix metalloproteinase (MMP)-2, MMP-8 and MMP-9), their inhibitors (tissue inhibitor of MMP (TIMP)I and TIMP-2), interleukin-8 (IL-8), the platelet activating factor-receptor (PAF-R), syndecan-I and estrogen binding receptors (estrogen receptor (ER) $\alpha$, ER $\beta$ and G-coupled protein receptor (GPR) 30) as well as the proliferation marker $\mathrm{Ki}-67$.

Results: The influx of leukocytes as assessed by CD45 was strongest in the responders, thereafter in the controls and significantly lower in the non-responders. IL-8, PAF-R and MMP-9, all predominantly expressed in leukocytes, showed significantly reduced immunostaining in the group of non-responders, while ER $\alpha$ and GPR30 were more abundant in the non-responders, as compared to the controls.

Conclusion: The impaired leukocyte influx, as reflected by the reduced number of CD45 positive cells as well as decreased immunostaining of IL-8, PAF-R and MMP-9 in the non-responders, could be one explanation of the failed ripening of the cervix in post term women. If the decreased leukocyte influx is a primary explanation to absent ripening or secondary, as a result of other factors, is yet to be established. 


\section{Background}

The human uterine cervix is an extracellular matrix (ECM) organ. The cervical ripening at term is clinically recognized as softening and dilation. This process corresponds to a remodelling of the cervical ECM with a changed proteoglycan composition and an increased collagen turnover resulting in differently organized collagen fibrils $[1,2]$. This remodelling of the cervix is necessary for a normal onset and progress of parturition.

The ripening process is characterized by inflammatory events, such as extravasation of neutrophils and macrophages [3-5] and an increased cervical level of pro-inflammatory cytokines such as interleukin (IL)-8 [4,6]. Postterm pregnancies, gestational length of $>42$ weeks, are associated with increased rates of maternal and fetal complications $[7,8]$. Among mothers delivering post term there is a significant risk in subsequent post term births, indicating that there are factors, genetic or other, that influence pregnancy length [9]. It is common practice worldwide to induce parturition when gestational age increases beyond 41 weeks, since the risk of complications is increasing after week $41[10,11]$. In Sweden there is a consensus to induce labour after 42 weeks of gestation. Most women respond to cervical prostaglandin application and labour is induced, but there is a group of women where no progress is achieved [12].

In previous studies we have shown that expression of estrogen receptor (ER) $\alpha$ and ER $\beta$ are varying in cervix biopsies obtained from women that are non pregnant, term pregnant or immediately postpartum $[3,13]$. Recently several articles regarding a specific estrogen receptor in the cell membrane, the G-protein coupled receptor 30 (GPR30) have been published [14-16]. GPR30 has been described in endometrial and ovarian cancer cells, but to our knowledge nothing is known from in vivo expression in the human cervix.

Platelet-activating factor (PAF) is a lipid pro-inflammatory mediator, involved in several reproductive processes, i.e. parturition [17]. PAF is a phospholipid synthesized by leukocytes, blood platelets and vascular endothelial cells [18]. PAF-R is a G-protein coupled membrane receptor with an estrogen responsive element within its promoter region, enabling regulation by estrogens [19]. We have found that immunostaining of PAF-R was higher in cervical stroma in term pregnant women than immediately after delivery [20]. The activation of the PAF-R is associated with cytoskeletal remodelling and expression of proinflammatory modulators, such as COX-2, IL-6 and IL-8 [21].

In a previous study we identified cervical stromal fibroblasts and smooth muscle cells as main sources of matrix metalloproteinase (MMP)-2, whereas the MMP-9 protein was observed exclusively in invading leukocytes [22]. Both MMPs were shown to be increased in the end of pregnancy as compared to cervical biopsies from nonpregnant women [22]. These data indicate the involvement of MMP-2 and MMP-9 in the cervical ripening process. The MMP family consists of more than 20 members with broad substrate specificities [23]. Main substrates for collagenases (MMP-1, -8, and -13) are fibrillar and nonfibrillar collagens. Primary targets of gelatinases (MMP-2 and -9) are denatured collagen IV, elastin, proteoglycans and fibronectin [24]. Syndecan-1 (S-1) is a cell surface proteoglycan that binds cells to the extracellular matrix and acts as a regulator of chemokine function [25]. In rat uterus, using microarray technology, we found that S-1 was clearly estrogen dependent [26]. Ki-67 is a marker for proliferation, and estrogens are known to induce cellular proliferation [27]. Thus, detection of S-1 and Ki-67 could indicate level of estrogen stimulation.

The aim of this study was to determine the parameters described above, in the cervix at term after spontaneous vaginal delivery in comparison to that of women with unripe cervices post term, both those responding to prostaglandin treatment and those who did not respond, to find out possible differences.

\section{Methods}

All women were nulliparous healthy, non-smoking, had uncomplicated pregnancies and were without medication. The gestational length was estimated according to ultrasound dating in the second trimester of gestation.

The post term groups consisted of women with an unripe cervix defined as a Bishop score $\leq 5$ points. Prostaglandin$\mathrm{E}_{2}$ in viscous gel (Minprostin ${ }^{\circledast}$ Pharmacia, Sweden) was administered locally to induce cervical priming. Oxytocin infusion (Syntocinon ${ }^{\circledR} 10 \mathrm{U}$ /glucose $5.5 \% 500 \mathrm{~mL}$ ) for augmentation of labour was administered to every woman in the responder group $5 \mathrm{~h}$ after the latest prostaglandin application, to a five out of ten women in the nonresponder group $5 \mathrm{~h}$ after the latest prostaglandin application and to all woman in the control group during the active phase of labour, if failure to progress after $2 \mathrm{~h}$ according to the clinical guidelines [28].

The group that responded to Miniprostin treatment (responders $=R, n=13$ ), i.e. who underwent vaginal parturition after successful cervical priming and labour induction (biopsy obtained immediately post partum) had a mean age $( \pm S D)$ of 29.4 years \pm 5.8 , a median gestational length of $42+4$ weeks (range $42+1$ to $42+6$ ), and a median Bishop score of 3 points (range 0-4) before treatment. This group received a median of total prostaglandin treatment of $1.0 \mathrm{mg}$ (range 1.0-2.0). 
The group of women who did not respond (non-responders $=N R, n=10$ ) to Miniprostin priming, i.e. experienced a failed induction (biopsy taken after caesarean section), had a mean age of 30.6 years \pm 1.9 , a median gestational length of $42+4$ weeks (range $42+3$ to $42+6$ ) and a mean Bishop score of 2 points (range 0-4) before treatment. These women received a median of 4.0 (range $0.5-7.0$ ) mg of prostaglandin treatment.

As controls we collected biopsies immediately after delivery from women who had a spontaneous onset of labour and underwent vaginal delivery at normal gestational length (controls $=\mathrm{C}, \mathrm{n}=18$ ). These women had a mean age of 29.3 years \pm 4.9 and a median gestational age of $40+1$ weeks (range $37+0$ to $41+1$ ).

Cervical biopsies (150-300 mg) were taken transvaginally at the 12 o'clock position at partus or immediately after emergency caesareans, by one physician (YSV). The study was approved by the Local Ethics Committee (Dnr 99099), and informed consent was obtained from all women before biopsies were collected. The biopsies were when possible divided into 2 pieces, one immediately frozen and the other was immersion-fixed in $4 \%$ formaldehyde at $4{ }^{\circ} \mathrm{C}$ overnight, stored at $4{ }^{\circ} \mathrm{C}$ in $70 \%$ ethanol and thereafter embedded in paraffin. When the biopsy was too small to be divided, only a fixed sample was prepared, therefore RNA preparations are not available from all samples.

IL-8 immunostaining was also performed in samples from a previously published study, for details on the non-pregnant (NP), term pregnant (TP) and post partum (PP) groups, see Wang et al. [13]. The PP group is similar to the control group of the post term study, i.e. biopsies are obtained immediately after spontaneous vaginal delivery at term.

\section{RNA preparation and reverse transcription}

Total RNA from frozen cervical tissue samples was purified with the RNeasy ${ }^{\circledast}$ kit (Qiagen GmbH, Hilden, Germany) according to a procedure recommended by manufacturer for RNA isolation from fibrous tissues. Two $\mu \mathrm{g}$ of total RNA from each sample was reverse transcribed at $37^{\circ} \mathrm{C}$ for $60 \mathrm{~min}$ in a final volume of $30 \mu \mathrm{l}$ with a reaction mixture (Qiagen GmbH, Hilden, Germany) containing $1 \times$ RT buffer, dNTP mix (0.5 mM each dNTP), $600 \mathrm{ng}$ random primers (Invitrogen, Paisley, UK), 10 units RNase inhibitor (Superase-In, Ambion, Austin, TX), and $4 \mathrm{U}$ of Omniscript $^{\mathrm{TM}}$ reverse transcriptase (Qiagen).

\section{Real time PCR analysis}

The oligonucleotide primers for ER $\alpha, \mathrm{ER} \beta, \mathrm{GPR} 30, \mathrm{MMP}-$ 2, MMP-8, MMP-9, TIMP-1, TIMP-2, S-1, PAF-R and Cyclophilin A are presented in Table 1, as well as their pre- dicted sizes. Real time PCR was performed in a DNA Engine Opticon $^{\mathrm{TM}} 2$ System (MJ Research, Waltham, MA). For PCR, the cDNAs corresponding to 40-100 ng (see Table 1) RNA were added to $10 \mu$ l of Quantitect ${ }^{\mathrm{TM}}$ SYBR $^{\circledast}$ Green PCR mix (Qiagen) containing HotStarTaq DNA polymerase, PCR buffer, dNTP mixture and $0.3 \mu \mathrm{M}$ of each oligonucleotide primer in a final volume of $20 \mu \mathrm{l}$. The reactions were performed in opaque white $0.2 \mathrm{ml}$ low-profile strip tubes sealed with optical flat caps (TLS0851, TCS-0803, MJ Research, Waltham, MA). After initial incubation for $15 \mathrm{~min}$ at $95^{\circ} \mathrm{C}$, the samples were subjected to $40-44$ cycles of 10 s at $94^{\circ} \mathrm{C}, 15-20$ s at $55-58^{\circ} \mathrm{C}$ (see Table 1 ) and $20 \mathrm{~s}$ at $72^{\circ} \mathrm{C}$ with a final extension step at $72^{\circ} \mathrm{C}$ for $5 \mathrm{~min}$. All reactions were performed twice. The purity of PCR products was confirmed by a melting curve analysis in all experiments (data not shown). The oligonucleotide primers are listed in Table 1. All primers were designed to span an intron/exon boundary or to flank an intron, thus, amplification of contaminating DNA was eliminated. Each PCR assay included a negative control containing a RNA sample without reverse transcription. The primers were based on the sequences of the human genes. The primer pairs (Table 1) were designed with Primer3 software [29].

\section{Quantification of mRNA}

To standardize the quantification method, cyclophilin A was selected out of several tested housekeeping genes as an invariable internal control $(\mathrm{p}=0.482)$. The PCR amplification rate and the cycle threshold $(\mathrm{Ct})$ values were related to a standard curve using Opticon Monitor 3.0 software (MJ Research, Waltham, MA). The values of relative expression of genes of interest were normalized against the cyclophilin A product.

\section{Immunohistochemical analysis}

Immunostaining for the determination of $E R \alpha, E R \beta$, GPR30, MMP-9, cd45, cd68, S-1, Ki-67, IL-8 and PAF-R utilizing the avidin-biotin peroxidase complex (ABC) procedure was performed [30]. The $5 \mu \mathrm{m}$ paraffin sections prepared from cervical biopsies were first dewaxed in Bioclear (Bio-Optica, Milan, Italy), rehydrated and washed with phosphate-buffered saline (PBS; pH 7.4)) (ER $\beta$ and PAF-R in Tris-buffered saline (TBS)). Thereafter the sections were subjected to microwave antigen retrieval in $0.01 \mathrm{M}$ sodium citrate buffer ( $\mathrm{pH} \mathrm{6.0)}$ for $10 \mathrm{~min}$ and then allowed to cool for $20 \mathrm{~min}$. Subsequently, endogenous peroxidase activity was quenched by immersion in $3 \%$ hydrogen peroxide (Merck) in methanol for $10 \mathrm{~min}$ at room temperature; followed by blocking non-specific binding of the primary antibody by incubation as shown in Table 2, at room temperature (RT). The sections were then incubated with the primary antibodies (see Table 2). For the negative controls the primary antibody was replaced by mouse IgG (or in the case of GPR30 rabbit 
Table I: Oligonucleotide primers used for real-time PCR, template amount and their annealing temperatures.

\begin{tabular}{|c|c|c|c|c|c|}
\hline Gene & Accession No. or Reference & $\begin{array}{l}\text { Primer } \\
F=\text { forward; } R=\text { reverse }\end{array}$ & Position & cDNA & Annealing step \\
\hline \multirow[t]{3}{*}{ MMP-2 } & BC002576 & F: gtatttgatggcatcgctca & bp $1695-1714$ & $40 \mathrm{ng}$ & $56^{\circ} \mathrm{C} / 20 \mathrm{~s}$ \\
\hline & & $\mathrm{R}$ : cattccctgcaaagaacaca & bp $|89|-|87|$ & & \\
\hline & & & product bp 198 & & \\
\hline \multirow[t]{3}{*}{ MMP-8 } & NM_002424 & F: ctttcagggaaaccagcaac & bp $790-809$ & $80 \mathrm{ng}$ & $55^{\circ} \mathrm{C} / 20 \mathrm{~s}$ \\
\hline & & R: gcttggtccagtaggttgga & bp $893-874$ & & \\
\hline & & & product bp 104 & & \\
\hline \multirow[t]{3}{*}{ MMP-9 } & BC006093 & F: cgctaccacctcgaactttg & bp $1124-1143$ & $40 \mathrm{ng}$ & $56^{\circ} \mathrm{C} / 20 \mathrm{~s}$ \\
\hline & & R: gccattcacgtcgtccttat & bp $1319-1300$ & & \\
\hline & & & product bp 198 & & \\
\hline \multirow[t]{3}{*}{ TIMP-I } & NM_003254 & F: tgacatccggttcgtctaca & bp 299-318 & $40 \mathrm{ng}$ & $56^{\circ} \mathrm{C} / 20 \mathrm{~s}$ \\
\hline & & R: tgcagttttccagcaatgag & bp $400-381$ & & \\
\hline & & & product bp 102 & & \\
\hline \multirow[t]{3}{*}{ TIMP-2 } & PMID & F: gagcctgaaccacaggtacca & bp $728-748$ & $40 \mathrm{ng}$ & $58^{\circ} \mathrm{C} / 15 \mathrm{~s}$ \\
\hline & & $\mathrm{R}:$ tctgtgacccagtccatcca & bp $841-822$ & & \\
\hline & & & product bp 114 & & \\
\hline \multirow[t]{3}{*}{ PAF-R } & NM_000952 & F: cagagacacacggtcactgc & bp 44-63 & $40 \mathrm{ng}$ & $56^{\circ} \mathrm{C} / 15 \mathrm{~s}$ \\
\hline & & $\mathrm{R}$ : catgtgggaggagtcatgtg & bp $154-135$ & & \\
\hline & & & product bp III & & \\
\hline \multirow[t]{3}{*}{ S-I } & NM_002997 & F: ggagcaggacttcacctttg & bp $869-888$ & $50 \mathrm{ng}$ & $59^{\circ} \mathrm{C} / 30 \mathrm{~s}$ \\
\hline & & R: cccagcacctctttcctgt & bp $1009-99 \mid$ & & \\
\hline & & & product bp 141 & & \\
\hline \multirow[t]{3}{*}{$\mathrm{ER} \alpha$} & NM_000I25 & F: cttgctcttggacaggaacc & bp $1581-1600$ & $80 \mathrm{ng}$ & $56^{\circ} \mathrm{C} / 20 \mathrm{~s}$ \\
\hline & & R: tcctctccctgcagattcat & bp $1691-1672$ & & \\
\hline & & & product bp III & & \\
\hline \multirow[t]{3}{*}{$\operatorname{ER} \beta$} & NM_001437 & F: tgcggaacctcaaaagagtc & bp 7I5-734 & $80 \mathrm{ng}$ & $56^{\circ} \mathrm{C} / 20 \mathrm{~s}$ \\
\hline & & R: catccctctttgaacctgga & bp 854-835 & & \\
\hline & & & product bp 140 & & \\
\hline \multirow[t]{3}{*}{ GPR30 } & NM_001505 & F: agactgtgaaatccgcaacc & bp 364-383 & $100 \mathrm{ng}$ & $57^{\circ} \mathrm{C} / 15 \mathrm{~s}$ \\
\hline & & R: aagtgagcctggcatttgt & bp 663-644 & & \\
\hline & & & product bp 300 & & \\
\hline \multirow[t]{3}{*}{ Cyclophilin A } & XM_004890 & F: gtggtgtttggcaaagtgaa & bp $401-420$ & $40 \mathrm{ng}$ & $56^{\circ} \mathrm{C} / 20 \mathrm{~s}$ \\
\hline & & $R$ : tcgagttgtccacagtcagc & bp 516-497 & & \\
\hline & & & product bp 116 & & \\
\hline
\end{tabular}

IgG) at a corresponding concentration to the antibody it replaced.

The secondary biotinylated antibody (Table 3 ) was incubated as shown in Table 3, followed by incubation with an avidin-biotin horseradish peroxidase complex (Vectastain Elite, Cat\# PK-6100) for $30 \mathrm{~min}$ at RT. The site of the bound enzyme was visualized by the application of 3,3'-diaminobenzidine (DAB kit, DAKO, CA), a chromogen which produces a brown, insoluble precipitate when incubated with enzyme. The sections were counterstained with haematoxylin and dehydrated before they were mounted with Pertex (Histolab, Gothenburg).

To obtain negative controls for the immunohistochemistry assays, the mouse monoclonal antibodies were replaced by a normal mouse IgG of the same concentration as the primary antibody. The polyclonal GPR30 anti- body was replaced by normal goat IgG of equal concentration.

\section{Image analysis}

A Leica microscope and Sony video camera (Park Ridge, NJ, USA) connected to a computer with an image analysis system (Leica Imaging System Ltd, Cambridge, UK) was used to assess quantitative values from immunohistochemistry. The quantification of immunostaining was performed as described previously [30]. Thus, quantification of immunostaining was performed on the digitized images of systematic randomly selected fields of cervical stroma, from which non-stromal elements (e.g. epithelium and glands) were interactively removed. Ten to 12 fields of stromal cells were measured separately in each tissue section. By using color discrimination software, the total area of positively stained cells (brown reaction product) was measured, and expressed as a ratio of the total 
Table 2: Antibodies used in the study.

\begin{tabular}{|c|c|c|c|c|c|}
\hline Protein & Order number and company & Type & Dilution & Incub. time & Blocking \\
\hline CD45RB & $\begin{array}{l}\text { M0833 (B cells, } T \text { cells subsets, monocytes, macrophages and some granulocytes) DAKO } \\
\text { A/S. }\end{array}$ & $\begin{array}{l}\text { Mc mouse } \\
\text { anti-human }\end{array}$ & $\mathrm{I}: 200$ & $+4^{\circ} \mathrm{Co} / \mathrm{n}$ & D \\
\hline CD68 & M0876 (macrophages) DAKO A/S, Glostrup, Denmark & $\begin{array}{l}\text { Mc mouse } \\
\text { anti-human }\end{array}$ & $\mathrm{I}: 200$ & $+4^{\circ} \mathrm{Co} / \mathrm{n}$ & D \\
\hline MMP-9 & MS-8I7-P0, NeoMarkers Inc & $\begin{array}{l}\text { Mc mouse } \\
\text { anti-human }\end{array}$ & $\mathrm{I}: 400$ & RT $60 \mathrm{~min}$ & $\mathrm{D}$ \\
\hline IL-8 & sc-7332I, Santa Cruz Biotechnology, Inc & $\begin{array}{l}\text { Mc mouse } \\
\text { anti-human }\end{array}$ & $\mathrm{I}: 200$ & $+4^{\circ} \mathrm{Co} / \mathrm{n}$ & A \\
\hline PAF-R & 160600, Cayman chemical, & $\begin{array}{l}\text { Mc mouse } \\
\text { anti-human }\end{array}$ & $\mathrm{I}: 350$ & $+4^{\circ} \mathrm{Co} / \mathrm{n}$ & $\mathrm{E}$ \\
\hline $\begin{array}{l}\text { S-I } \\
(C D \mid 38)\end{array}$ & M7228, DakoCytomation, & $\begin{array}{l}\text { Mc mouse } \\
\text { anti human }\end{array}$ & $\mathrm{l}: 50$ & $\begin{array}{l}\text { RT } \\
30 \text { min }\end{array}$ & A \\
\hline $\mathrm{ER} \alpha$ & 2nd Gen 08-1 I49, Zymed Laboratories Inc & $\begin{array}{l}\text { Mc mouse } \\
\text { anti-human }\end{array}$ & $\mathrm{I}: 5$ & $+4^{\circ} \mathrm{Co} / \mathrm{n}$ & A \\
\hline ER $\beta$ & Serotec Ltd, MCAI 974 & $\begin{array}{l}\text { Mc mouse } \\
\text { anti-human }\end{array}$ & $\mathrm{I}: 20$ & $+4^{\circ} \mathrm{Co} / \mathrm{n}$ & B \\
\hline GPR30 & LS-A4272, LifeSpan BioSciences & $\begin{array}{l}\text { Pc rabbit } \\
\text { anti-human }\end{array}$ & $\mathrm{I}: 300$ & $\begin{array}{l}\text { RT } \\
60 \min \end{array}$ & C \\
\hline Ki-67 & NCL-Ki67-MMI, Novocastra Laboratories Ltd & $\begin{array}{l}\text { Mc mouse } \\
\text { anti human }\end{array}$ & $\mathrm{I}: 200$ & $+4^{\circ} \mathrm{Co} / \mathrm{n}$ & A \\
\hline
\end{tabular}

$M c=$ monoclonal; $\mathrm{Pc}=$ polyclonal, $\mathrm{A}=1.5 \%$ normal horse serum $(\mathrm{NHS})$ in PBS for $30 \mathrm{~min}, \mathrm{~B}=1.5 \%$ normal horse serum (NHS) in TBS containing $5 \%$ bovine serum albumin (BSA) for $45 \mathrm{~min}, \mathrm{C}=1.5 \%$ normal goat serum (NGS) in PBS containing $5 \%$ bovine serum albumin (BSA) for $30 \mathrm{~min}, \mathrm{D}=$ $1.5 \%$ normal horse serum (NHS) in PBS for $45 \mathrm{~min}, \mathrm{E}=1.5 \%$ normal horse serum (NHS) in TBS for $45 \mathrm{~min}$.

$\mathrm{NHS}=$ normal horse serum (Vector Laboratories, Burlingame, CA).

NGS = normal goat serum (DakoCytomation, Glostrup, Denmark).

area of cell nuclei (brown reaction product + blue haematoxylin).

\section{Manual scoring}

Two observers blinded to the identity of the slides (LS, $\mathrm{BM}$ ) performed all the assessments. The staining was eval- uated semi-quantitatively using a grading system. The staining intensity and amount of positive cells were graded on a scale of (0) no staining, (1) faint/few positive cells, (2) moderate $/ 20-50 \%$ cells positive and (3) strong staining/majority of cells positive.

Table 3: Secondary anti-bodies used in the study, their dilution, buffers and incubation time.

\begin{tabular}{|c|c|c|c|c|}
\hline Protein & 2nd Ab & Dilution & Buffer & Incubation \\
\hline CD45RB & $\begin{array}{l}\text { biotinylated horse } \\
\text { anti-mouse }\end{array}$ & $\mathrm{I}: 200$ & $1.5 \% \mathrm{NHS}$ in PBS & $60 \min R T$ \\
\hline CD68 & $\begin{array}{l}\text { biotinylated horse } \\
\text { anti-mouse }\end{array}$ & $\mathrm{I}: 200$ & $1.5 \% \mathrm{NHS}$ in PBS & $60 \min R T$ \\
\hline MMP-9 & $\begin{array}{l}\text { biotinylated horse } \\
\text { anti-mouse }\end{array}$ & $1: 200$ & $1.5 \%$ NHS in PBS & $60 \mathrm{~min} R T$ \\
\hline IL-8 & $\begin{array}{l}\text { biotinylated horse } \\
\text { anti-mouse }\end{array}$ & $1: 200$ & $1.5 \% \mathrm{NHS}$ in PBS & $30 \operatorname{minRT}$ \\
\hline PAF-R & $\begin{array}{l}\text { biotinylated horse } \\
\text { anti-mouse }\end{array}$ & $1: 200$ & $1.5 \% \mathrm{NHS}$ in TBS & $30 \min \mathrm{RT}$ \\
\hline $\begin{array}{l}\text { S-I } \\
(C D \mid 38)\end{array}$ & $\begin{array}{l}\text { biotinylated horse } \\
\text { anti-mouse }\end{array}$ & $\mathrm{I}: 200$ & $1.5 \% \mathrm{NHS}$ in PBS & $30 \min \mathrm{RT}$ \\
\hline $\mathrm{ER} \alpha$ & $\begin{array}{l}\text { biotinylated horse } \\
\text { anti-mouse }\end{array}$ & $\mathrm{I}: 200$ & $1.5 \% \mathrm{NHS}$ in PBS & $30 \min R T$ \\
\hline ER $\beta$ & $\begin{array}{l}\text { biotinylated horse } \\
\text { anti-mouse }\end{array}$ & $\mathrm{I}: 200$ & $1.5 \% \mathrm{NHS}$ in TBS + 5\% BSA & $60 \min \mathrm{RT}$ \\
\hline GPR30 & $\begin{array}{l}\text { biotinylated goat } \\
\text { anti-rabbit }\end{array}$ & $1: 200$ & $1.5 \% \mathrm{NGS}$ in $\mathrm{PBS}+5 \% \mathrm{BSA}$ & $30 \min \mathrm{RT}$ \\
\hline Ki67 & $\begin{array}{l}\text { biotinylated horse } \\
\text { anti-mouse }\end{array}$ & $1: 200$ & $1.5 \%$ NHS in PBS & $30 \min \mathrm{RT}$ \\
\hline
\end{tabular}




\section{Statistical analysis}

Statistical calculation was performed by a parametrical method (one way ANOVA followed by Scheffés test to evaluate significance) for patient age. For all other parameters statistical calculations were performed by the nonparametric method ANOVA on ranks (Kruskal-Wallis test) and significances were evaluated by Dunn's test. Values are considered significantly different when $P<0.05$.

\section{Results}

There was no difference between the study groups regarding age, and no difference between the R and NR groups in the Bishop score before treatment. The gestational age of the control group $(40+1)$ was significantly shorter than that of the R and NR groups $(42+4$ in both). The NR group received, as compared to the $\mathrm{R}$ group, significantly more prostaglandin (4 to $1 \mathrm{mg}$ in total) and had more times of application (3 to 1.5 times) before delivery.

Due to the very small biopsies we could collect there were just four samples available for the NR group in the PCR assays, why the power of those calculations is less than the 0.80 that is desired. Therefore we are less likely to detect a difference when one actually exists. We show the results for the mRNA determinations, even if there are no significant differences, to enable for the viewer to judge and to allow comparison with immunostaining results. In addition, the mRNA levels are determined in a RNA preparation from a homogenate of the cervical biopsy, why potential differences between different cell types could even out each other.

\section{Leukocytes}

Immunostaining of CD45 showed that there are less leukocytes in the NR group than in the responders (Figure 1, upper panel; Figure $2 \mathrm{~A}-\mathrm{C}$ ), indicating that prostaglandin treatment, when successful, induces leukocyte influx. CD68 immunostaining (Figure 2M) showed no significant difference between groups (Figure 1, middle panel).

\section{MMPs and TIMPs}

No significant differences in MMP-2 mRNA levels between the study groups were found $(p=0.57)$. There was a tendency to a decreased level of MMP-8 mRNA in the NR group as compared to the $\mathrm{C}$ and $\mathrm{R}$ groups ( $\mathrm{p}=$ 0.07) (Figure 3, upper panel). The MMP-9 mRNA level was lower in the NR group as compared to the controls (Figure 3, middle panel). Immunostaining with the MMP9 antibody showed that the leukocytes stained positive and scoring was not performed (Figure 2D-F).

There were no significant differences in the mRNA levels of TIMP- 1 and TIMP-2 between groups $(\mathrm{p}=0.103$ and $\mathrm{p}=$ 0.677 , respectively).

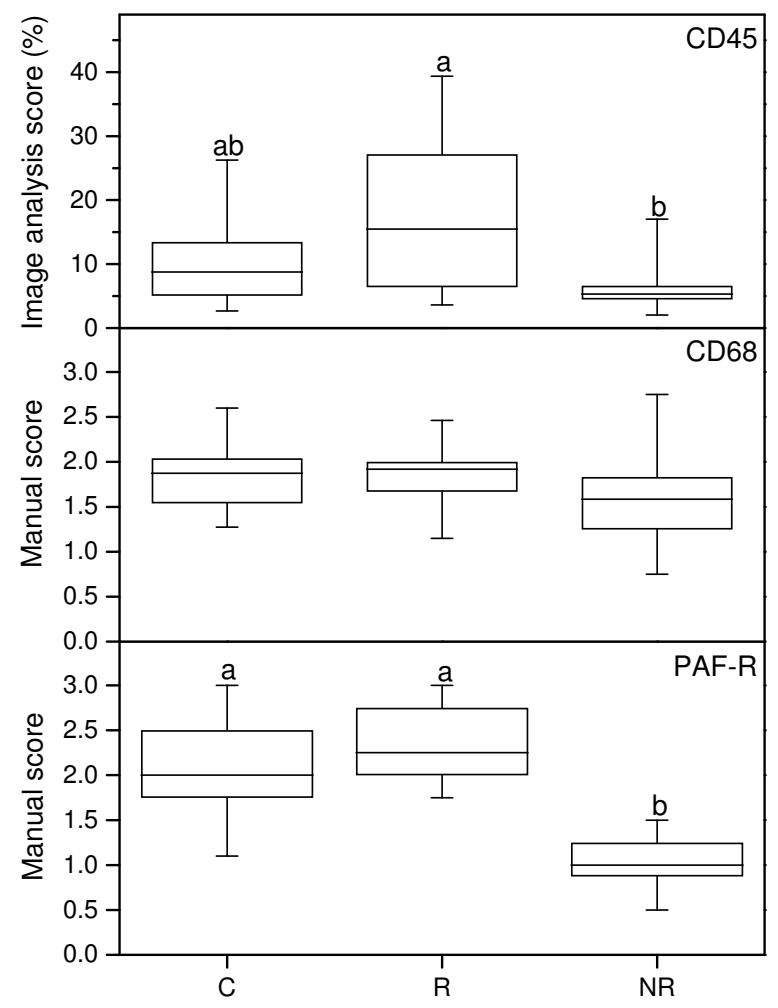

\section{Figure I}

Immunostaining results of CD45, CD68 and PAF-R. CD45 (top), CD68 (middle) and PAF-R (bottom) immunostaining results in stroma, as assessed by image analysis (top) and manual scoring (middle, bottom) in cervical samples from controls $(C)(n=18)$, responders $(R)(n=13)$ and nonresponders (NR) $(n=9)$. The "box-and-whisker plot" represents the median value with $50 \%$ of all data falling within the box. The whiskers extend to the 5 th and 95th percentiles. Boxes with different letter designations are significantly different, $p<0.05$.

\section{PAF-R}

The PAF-R mRNA level was lower in the NR group as compared with the controls (Figure 3, bottom panel). There is also less cells positively stained for PAF-R in the NR group, as compared to both the $\mathrm{R}$ and $\mathrm{C}$ groups (Figure 1, bottom panel; Figure 2G-I), when scoring the stroma which to a large extent contained positively stained leukocytes.

\section{IL-8}

Immunostaining of IL- 8 showed that there are more leukocytes staining positive in the cervix from women immediately post partum (PP), than in term pregnancy (TP) or non-pregnant (NP) (Figure 4A-C; Table 4). In addition, the glandular epithelium also stained more positive in the $\mathrm{PP}$ as compared to the NP group (Table 4). In the nonresponders of the present study, there were less IL-8 


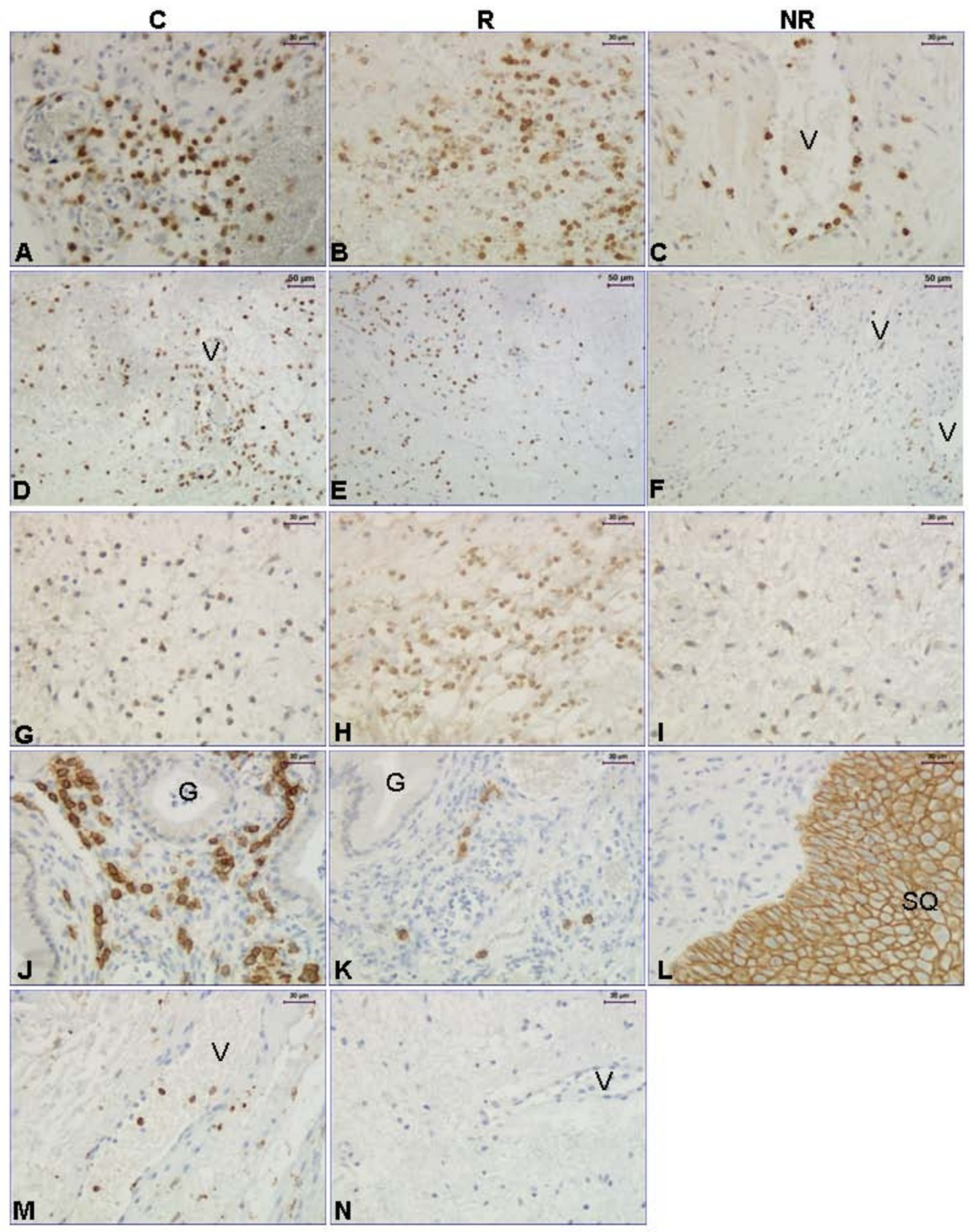

\section{Figure 2}

Representative images of CD45, MMP-9, PAF-R, syndecan-I and CD68 immunostaining. Representative images of the immunostaining results for CD45 (A-C), MMP-9 (D-F), PAF-R (G-I), Syndecan-I (J-L) and CD68 (M). A negative control is shown for monoclonal antibodies $(\mathbf{N})$ where the primary antibody (in this example CD45) was replaced by an equal amount of mouse lgG. Abbreviations: G: gland; V: vessel and SQ: squamous epithelium. The magnification bars represent $30 \mu \mathrm{m}$ in all images but D-F, where it is $50 \mu \mathrm{m}$. 


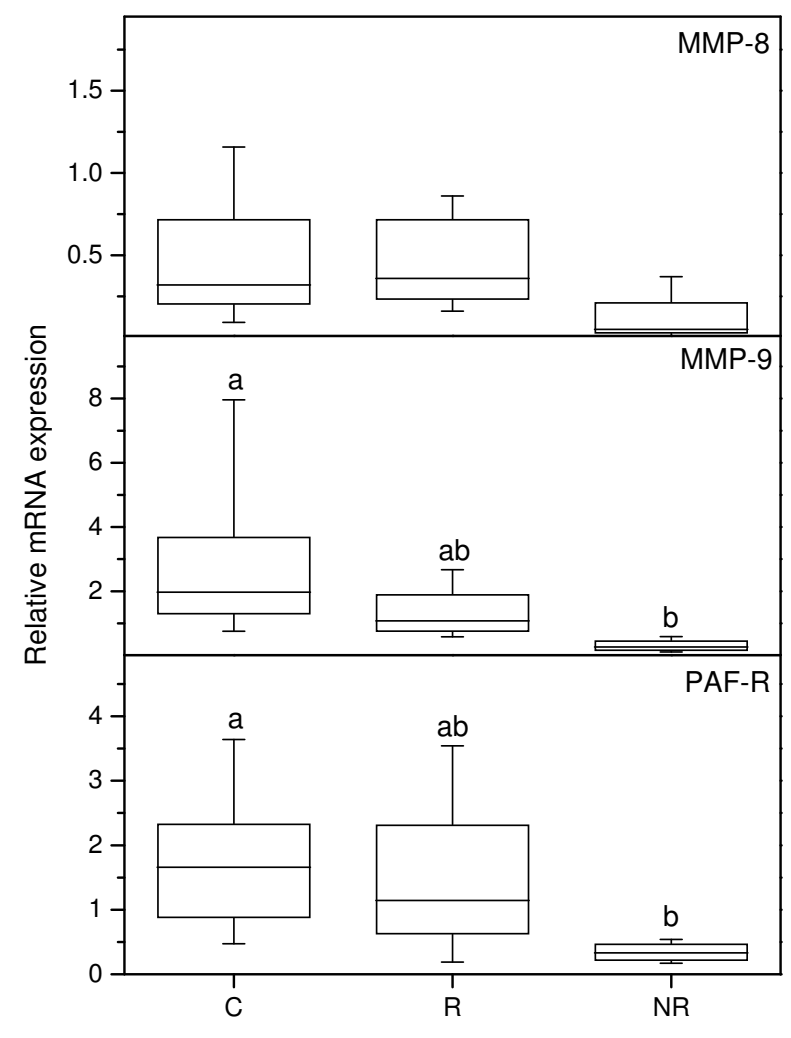

Figure 3

PCR results for MMP-8, MMP-9 and PAF-R. Representative real-time PCR experiments for expression of MMP-8 (upper), MMP-9 (middle) and PAF-R (bottom) mRNAs in human cervix from the $C(n=I I), R(n=10)$ and NR $(n=4)$ groups respectively. The values of relative expression of target genes were normalized against cyclophilin A and displayed in arbitrary units. The "box-and-whisker plot" represents the median value with $50 \%$ of all data falling within the box. The whiskers extend to the 5 th and 95th percentiles. Boxes with different letter designations are significantly different, $p<0.05$.

immunopositive leukocytes as compared to both the responders (R) and the controls (Figure 4D-F; Table 4). A negative control, where the primary antibody was replaced by a equal amount of mouse IgG, is shown in Figure 4G.

\section{Syndecan-I}

The syndecan-1 (S-1) mRNA level did not differ significantly between the groups. Over all stromal S-1 immunostaining did not differ between the groups, but when we scored stroma close to glands and stroma close to squamous epithelium separately, there were significantly more S-1 immunostaining in the stroma close to glands in the
C group $(\mathrm{n}=7)$, as compared to the responders $(\mathrm{n}=3)(\mathrm{p}$ $=0.042$ ) (Figure $2 \mathrm{~J}$ and $2 \mathrm{~K}$, respectively). There were not glands present in all samples why the number of samples analyzed is less for S-1, and only one sample from the NR group had glands, why we could do no statistical comparison to that group. The squamous epithelium was strongly stained in all groups (Figure 2L). A representative image of the negative control for the monoclonal antibodies is shown in Figure 2N.

\section{Estrogen receptors and $\mathrm{Ki}-67$}

\section{$E R \alpha$}

There are no significant differences in the mRNA level between the study groups (Figure 5, upper panel), but the protein level in stroma was significantly lower in the control group as compared to the R and NR groups (Figures 6 , upper panel; Figure 7A-C).

\section{$E R \beta$}

No significant differences in the mRNA level between groups were found (Figure 5, middle panel). A tendency to more immunostaining in the stroma was found in the NR group as compared to controls $(\mathrm{p}=0.073)$ (Figure 6 , middle panel; Figure 7D-F).

\section{GPR30}

The mRNA levels of GPR30 did not differ between groups (Figure 5, bottom panel). Immunostaining of GPR30 in cervical stroma was stronger in the NR group as compared to controls (Figure 6, bottom panel; Figure 7G-I).

Ki-67

Immunostaining with the antibody directed towards the proliferation marker Ki-67 showed no differences between groups (data not shown). Typically the squamous epithelium was positive while most stroma cells were negative (Figure $7 \mathrm{~K}$ ).

A representative image of the negative controls for the monoclonal antibodies is shown in Figure 7J, while a negative control for the polyclonal GPR-30 antibody is shown in Fig 7L.

\section{Discussion}

Impaired cervical ripening is a dominating feature in post term pregnancy. The trigger initiating the normal cervical softening including remodelling of the cervical ECM is unclear. The 100-fold increase of estradiol and progesterone concentrations, as a result of the placental production, in peripheral maternal blood at term pregnancy may support a role for hormonal regulation. Furthermore, the significant higher level of fetal fibronectin in cervical mucus after successful ripening with prostaglandin-E2 supports a possible fetal role in the onset of labour [31]. 


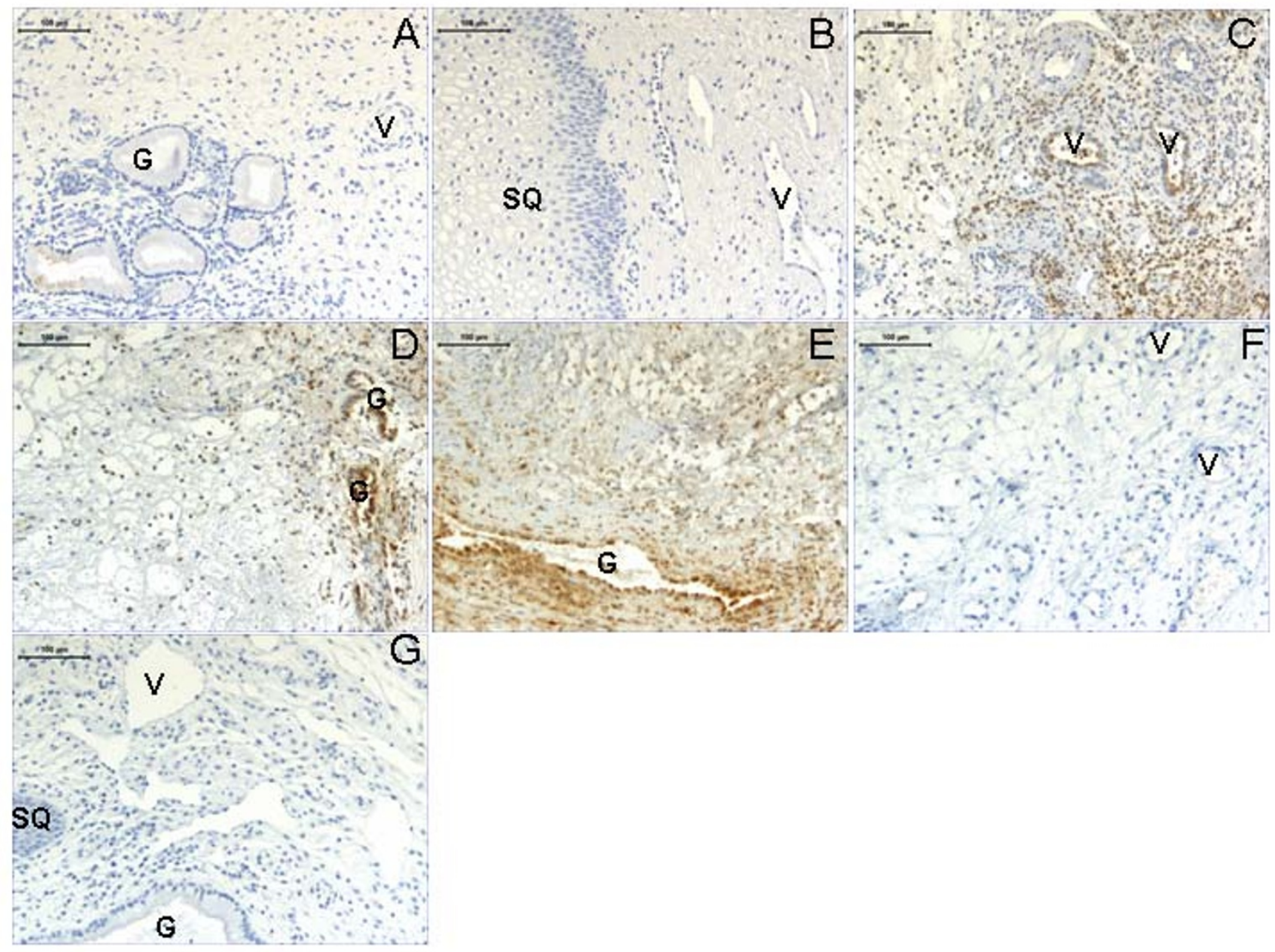

\section{Figure 4}

Representative images of IL-8 immunostaining. Representative images of IL-8 immunostaining of cervical biopsies from women non-pregnant (A), term pregnant (B), post partum (C). Second row shows images from women delivered spontaneously at term (D), post term women responding to prostaglandin priming (R group) delivering vaginally (E) and post term women who did not respond to prostaglandin treatment (NR group) and was delivered by caesarean section (F). A negative control where the primary antibody was replaced by an equal amount of mouse $\lg G$, is shown in (G). Abbreviations: $V$ : vessel; $\mathrm{G}$ : gland and SQ: squamous epithelium. Magnification bars represent $100 \mu \mathrm{m}$ in all images.

In previous studies we have been able to show that there are decreased levels of stromal ER $\alpha$ and ER $\beta$ in human cervix immediately post partum as compared to the nonpregnant state and term, respectively [13]. In the present study the NR group showed an increased level of ER $\alpha$ immunostaining compared to the controls whereas ER $\beta$ showed a tendency to increased immunostaining, indicating a possibility of increased ER $\alpha$ and ER $\beta$ levels to be a sign of decreased spontaneous cervical ripening. However, there were no differences in Ki-67 immunostaining between groups, indicating no change in estrogen response regarding proliferation in the cervix.
In studies on human leukocytes we have found expression of both ER $\alpha$ and ER $\beta$, the mRNA in several splice variants and the protein in different sizes both in mononuclear and polymorphonuclear cells [32]. Leukocytes from rats treated with selective ER agonists expressed several genes associated to extracellular matrix remodelling [33]. Further studies to evaluate if these genes are involved in the cervix remodelling in humans are needed.

The recent discovery of GPR30 as an estrogen binding membrane receptor, made us interested to describe its expression in the human cervix. GPR30 immunostaining 
Table 4: Scoring results of IL-8 immunostaining.

\begin{tabular}{lcc}
\hline IL-8 & $\begin{array}{c}\text { Leukocytes } \\
\text { (median and range) }\end{array}$ & $\begin{array}{c}\text { Glandular epithelium } \\
\text { (median and range) }\end{array}$ \\
\hline$N P(n=6)$ resp $(n=4)$ & $0(0-1)$ & $0(0-1)$ \\
TP $(n=8)$ resp $(n=5)$ & $0(0-1)$ & $1(0-1)$ \\
PP $(n=10)$ resp $(n=10)$ & $2(1-2) \S$ & $2(I-3) *$ \\
\hline$C(n=18)$ resp $(n=9)$ & $2(1-3)$ & $2(1-3)$ \\
$R(n=13)$ resp $(n=2)$ & $2(I-3)$ & \\
$N R(n=10)$ resp $(n=1)$ & $0(0-3) \#$ & \\
\hline
\end{tabular}

Glandular epithelium (GE) was not present in all samples why the $n$ is less there. In the post term study it was not possible to do statistical calculations of IL-8 immunostaining in GE.

$\S=$ significantly different to NP and TP groups.

$*$ = significantly different to the NP group.

\# = significantly different from the $C$ and $R$ groups.

was significantly increased in the NR group as compared to controls. Thus, this estrogen binding protein behaved similarly to ER $\alpha$ and ER $\beta$. More studies are needed to elucidate this increase in estrogen binding proteins in the cervix from post term non-responders compared to those that delivered spontaneously at term. In the hamster ovary GPR30 was shown to be regulated by the gonadotropins $\mathrm{LH}$ and FSH, whereas estrogen and progesterone had no effect, when given to hypophysectomized animals [34].

Cervical ripening has been shown to involve an inflammatory reaction, including leukocyte influx and activated fibroblasts $[3-6,20,22,35,36]$. In the present study it is notable that IL-8, PAF-R and MMP-9, all predominantly expressed in leukocytes, are significantly reduced in the NR group. For IL-8, the level in the NR group is comparable to that in cervix from non-pregnant women. The decrease found could be a secondary effect due to the impaired accumulation of leukocytes in the non-responders, since they demonstrated a lower level of leukocytes as measured by CD45 immunoreactivity, in comparison to the group responding to prostaglandin treatment.

We have previously shown that CD45 positive cells are increased in the cervix of women in term pregnancy and immediately post partum as compared to the non-pregnant [3]. No differences were found between term and post partum, hence the actual delivery does not seem to change the leukocyte influx. This differs from the results by Timmons and Mahendroo, who showed that in mice the leukocyte invasion occurs in labour and not due to ripening of the cervix. They also conclude that a role for neutrophils is more probable in postpartum remodelling of the cervix, rather than in the initiation of cervical ripening at parturition [37]. Another group stated though that the above study is the only one showing no increase of neutrophils prior to parturition in mice, and speculate that the different way of measuring immune cells (in a suspension of tissue with a hemacytometer) could be the reason for the different result [38]. Yellon et al. concluded that wild-type mice demonstrate an increased presence of macrophages, as well as reduced collagen structure in the cervix in late pregnancy, which is consistent with the hypothesis that recruitment of macrophages is important for cervical remodelling before term [38].

In the present study the influx of CD45 positive leukocytes is strongest in the $\mathrm{R}$ group, thereafter the $\mathrm{C}$ group and significantly lower in the NR group. Thus, if the postterm women were able to react on prostaglandin treatment the accumulation of leukocytes was restored to, or even tended to overcome, that of the level in the cervix of women delivering spontaneously at term. Post term women could be divided into at least two subgroups, those with non-ripe cervices that with the correct stimulus, like the prostaglandin gel, could progress into labour and a vaginal delivery; and those that fail to respond to prostaglandin stimulation and have to be delivered by caesarean section.

In term and preterm cervical ripening mRNAs of the three isomers of NOS, nNOS, eNOS and iNOS have been identified. An increased expression of nNOS was registered at preterm cervical ripening [39]. One of the few articles which present results from studies on cervix in post term women showed reduced cervical nitric oxide release in cervical fluid of post term compared to term women [40]. This decrease in NO levels is in agreement with the decreased level of leukocytes found in our study, since certain leukocytes are known to express iNOS [41].

Platelet activating factor (PAF) is a pro-inflammatory mediator, which has been implicated in parturition. Local application of PAF in rats induced cervical ripening [35], whereas a PAF-receptor (PAF-R) antagonist prolonged parturition [42]. The PAF-R has been identified in human 


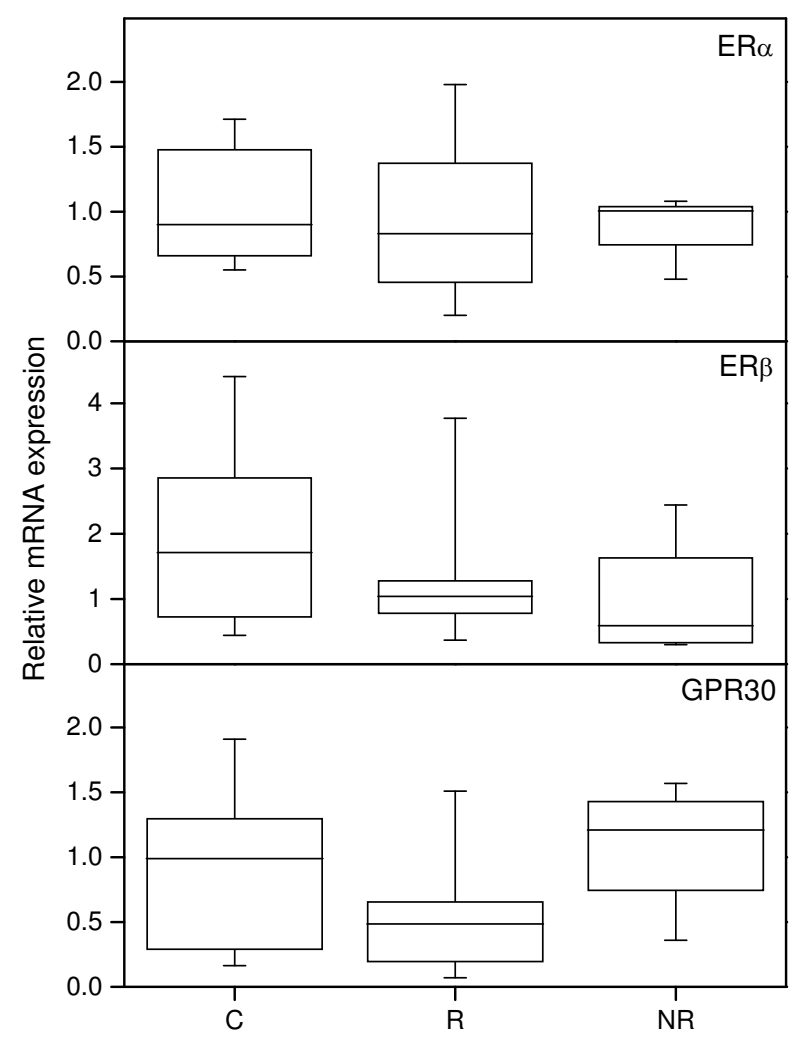

\section{Figure 5}

PCR results for ER $\alpha, E R \beta$ and GPR30. Representative real-time PCR experiments for expression of ER $\alpha$ (upper), ER $\beta$ (middle) and GPR30 (bottom) mRNAs in human cervix from the $C(n=I I), R(n=10)$ and $N R(n=4)$ groups respectively. The values of relative expression of target genes were normalized against cyclophilin $A$ and displayed in arbitrary units. The "box-and-whisker plot" represents the median value with $50 \%$ of all data falling within the box. The whiskers extend to the 5 th and 95 th percentiles.

cervical fibroblasts in vitro [43]. We have previously shown presence of the PAF-R protein in the human uterine cervix in vivo [20]. Stromal PAF-R immunostaining was most pronounced at term, and decreased after parturition. PAF increases the expression of pro-inflammatory cytokines e.g. IL-8, and this effect can be abolished using a PAF-R antagonist (WEB2170) $[17,43]$. In the immortalized sebaceous gland cell line SZ95 PAF-R activation has been shown to induce expression of cyclooxygenase-2, prostaglandin-E2 and IL-8 [44]. Thus, the PAF-R has the potential to induce these factors, all which have been shown to be involved in the process of cervical ripening $[4,20]$. In the present study the PAF-R expression was lower in the NR group, possibly due to the lower level of leukocytes present in this group. The amount of PAF-R might require a certain level to be able to induce cervical

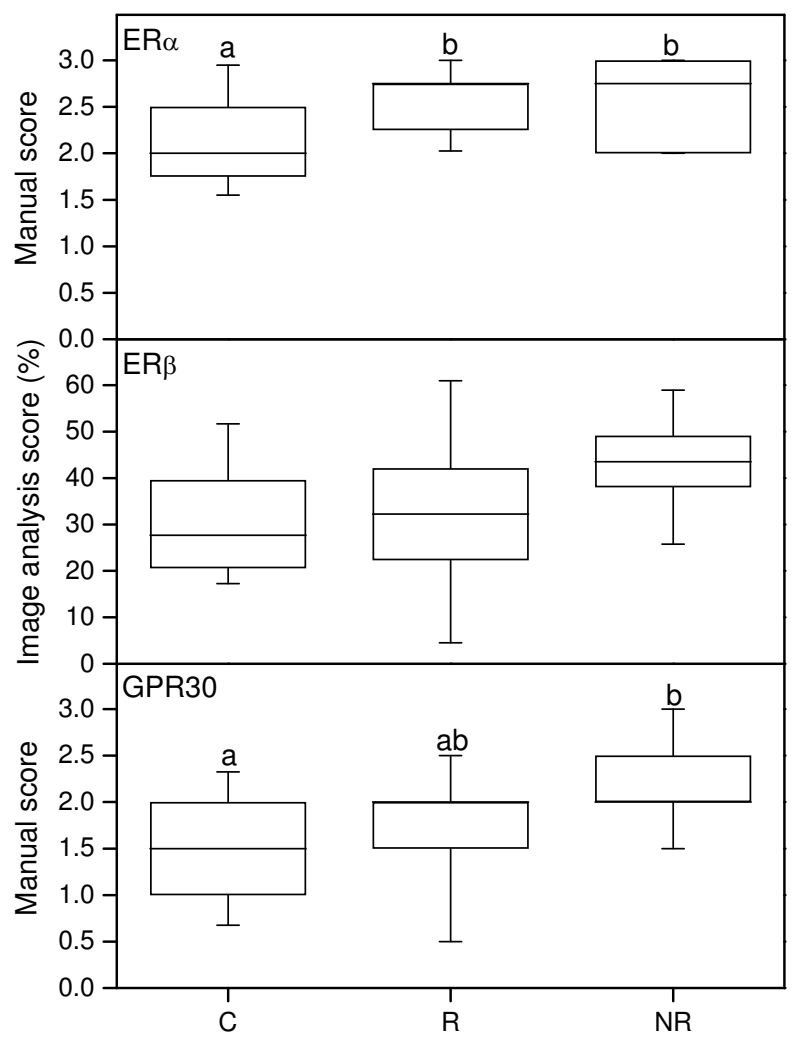

Figure 6

Immunostaining results of ER $\alpha, E R \beta$ and GPR30. ER $\alpha$ (top), ER $\beta$ (middle) and GPR30 (bottom) immunostaining results in stroma, as assessed by manual scoring (top, bottom) and image analysis (middle) in cervical samples from controls $(C)(n=18)$, responders $(R)(n=13)$ and nonresponders $(N R)(n=9)$. The "box-and-whisker plot" represents the median value with $50 \%$ of all data falling within the box. The whiskers extend to the 5 th and 95 th percentiles. Boxes with different letter designations are significantly different, $p<0.05$.

ripening in response to activation. Lack of activation might then reduce or inhibit the pro-inflammatory modulators that have been shown to be the response to PAF-R activation [21]. This is well in agreement with our present results showing a lower level of IL- 8 in the post term group not responding to prostaglandin priming.

The remodelling of the cervical ECM includes both increased synthesis as well as degradation of collagen fibrils and proteoglycans. MMP-2 and MMP-9 expression in human cervix increase at term pregnancy, suggesting involvement of these proteases in the reorganization of ECM during cervical ripening. In the human cervix, MMP2 and MMP-9 are produced by different cell types: MMP2 was immunolocalized mainly to stromal fibroblasts and 


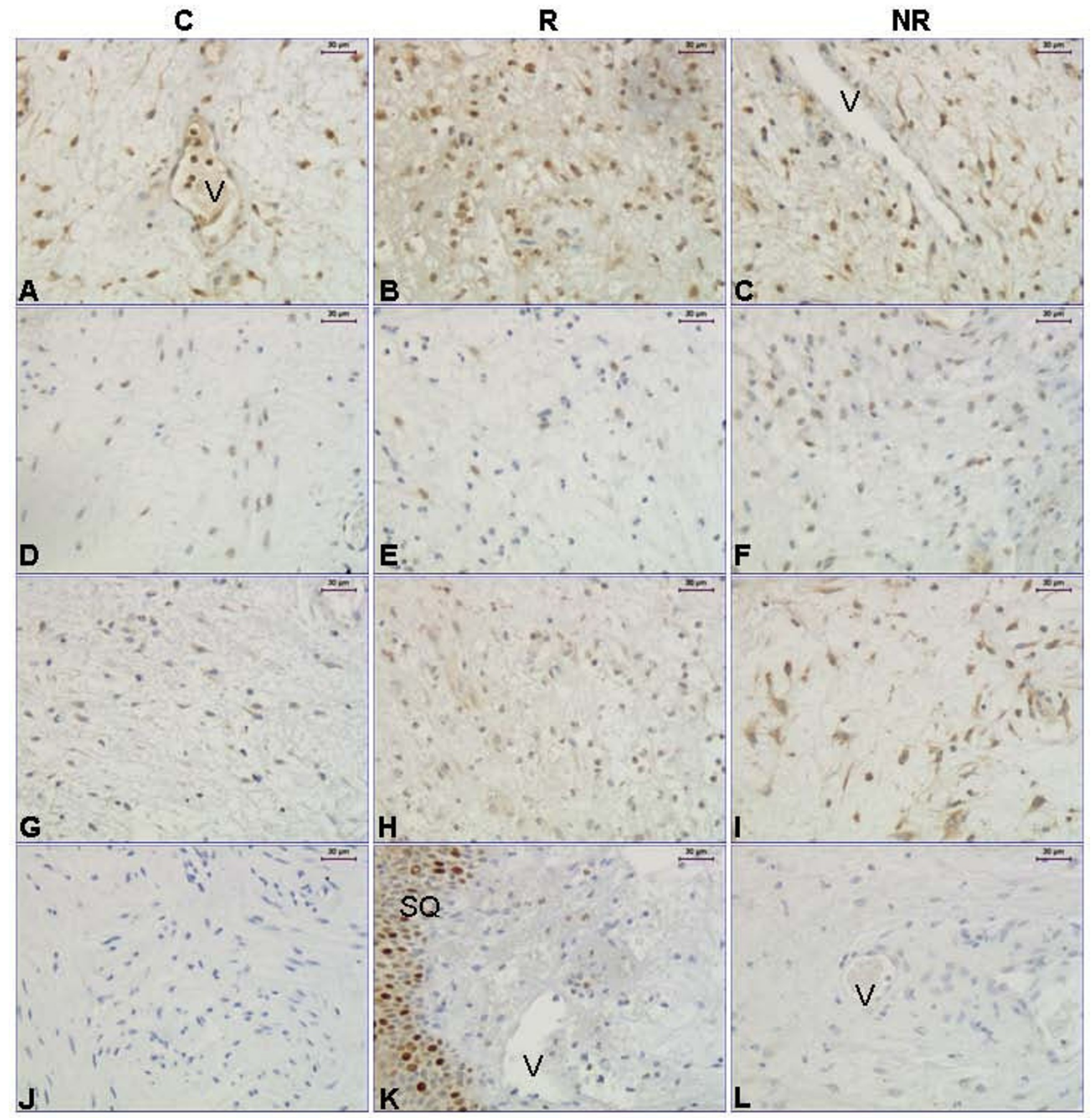

\section{Figure 7}

Representative images of ER $\alpha, E R \beta$, GPR30 and Ki-67 immunostaining. Representative images of the immunostaining results for ER $\alpha(\mathbf{A}-\mathbf{C}), \operatorname{ER} \beta(\mathbf{D}-\mathbf{F})$, GPR30 (G-I) and Ki-67 (K), and a negative control for monoclonal antibodies (J) where the primary antibody (in this example ER $\alpha$ ) was replaced by an equal amount of mouse lgG. A negative control for the GPR30 polyclonal antibody, where the primary antibody was replaced by an equal amount of goat lgG, is shown in (L). Abbreviations: V: vessel and SQ: squamous epithelium. Magnification bars represent $30 \mu \mathrm{m}$ in all images. 
smooth muscle cells, whereas MMP-9 was observed exclusively in leukocytes [22]. Taken together with our present results, data indicate the importance of leukocyte derived MMP-9 for a spontaneous cervical ripening process. Leukocytes are recognized as a main source of the catabolic enzymes involved in the remodelling of the cervix during parturition [45]. The present results suggest that the lower level of leukocytes lead to a less intensive inflammatory event and therefore impaired or absent cervical ripening. The decrease in MMP-9 and PAF-R could be secondary to the lower leukocyte count.

The syndecan family of transmembrane proteoglycans is the major source of cell surface heparane sulphates (HS) on all cell types. Recent in vitro and in vivo data suggest the involvement of syndecans in the modulation of leukocyte-endothelial interactions and extravasation, the formation of chemokine gradients, participation in chemokine and growth factor signalling, as well as repair processes [46]. In vitro IL-8 has been shown to shed from endothelial cells bound to S-1 and HS, and increased shedding was accompanied by a significant decrease in the number of neutrophils migrating across the endothelium [47]. Thus, S-1 could be involved in the influx of leukocytes and the cytokine presentation in the tissue. We found an increased level of S-1 adjacent to glands in the controls, where we also found strong immunostaining for IL-8. In two recent articles S-1 expression in human endometrium during the menstrual cycle has been described $[48,49]$. Although the function of S-1 in normal endometrium is not known, the changes in expression related to the hormonally regulated menstrual cycle $[48,49]$ and after estrogen treatment to ovariectomized rats [26], suggest a possible role of S-1 in hormone regulated tissue remodelling. In addition S-1, as well as Ki-67, is primarily expressed in cervix epithelium, where also $\mathrm{ER} \alpha$ and ER $\beta$ expression is most pronounced [13].

\section{Conclusion}

Failed induction of cervical ripening and delivery of post term pregnant women was associated with decreased accumulation of leukocytes, possibly resulting in the lower levels of factors important for remodelling of the ECM, such as PAF-R and MMPs determined in the present study. If the decreased leukocyte influx is the primary cause, or the secondary result of another factor, maternal and/or fetal, have to be investigated further.

\section{Competing interests}

The authors declare that they have no competing interests.

\section{Authors' contributions}

LS, YSV and GEO participated in the design of the study. All samples were collected by YSV. The analyses of proteins and mRNAs were carried out by BM and LS. Data analyses were performed by BM and LS. NR and GEO have helped to draft the manuscript, and the manuscript was written by LS. All authors have read and approved the final manuscript.

\section{Acknowledgements}

We thank Denis Stygar for technical assistance in the initiation of this project.

This study received financial support from The Swedish Research Council (projects 73X-20I37 (LS) 73X-I46I2 (GE)), The Swedish Society of Medicine (LS) and Karolinska Institutet. Financial support was also provided through the regional agreement on medical training and clinical research (ALF) between Stockholm County council and Karolinska Institutet.

\section{References}

I. Ekman G, Malmstrom A, Uldbjerg N, Ulmsten U: Cervical collagen: an important regulator of cervical function in term labor. Obstet Gynecol 1986, 67:633-636.

2. Uldbjerg N, Ekman G, Malmstrom A, Olsson K, Ulmsten U: Ripening of the human uterine cervix related to changes in collagen, glycosaminoglycans, and collagenolytic activity. Am J Obstet Gynecol 1983, 147:662-666.

3. Stygar D, Wang H, Vladic YS, Ekman G, Eriksson H, Sahlin L: Colocalization of oestrogen receptor beta and leukocyte markers in the human cervix. Mol Hum Reprod 200I, 7:88I-886.

4. Osman I, Young A, Ledingham MA, Thomson AJ, Jordan F, Greer IA, Norman JE: Leukocyte density and pro-inflammatory cytokine expression in human fetal membranes, decidua, cervix and myometrium before and during labour at term. Mol Hum Reprod 2003, 9:4I-45.

5. Yellon SM, Mackler AM, Kirby MA: The role of leukocyte traffic and activation in parturition. J Soc Gynecol Investig 2003, 10:323-338.

6. Sennstrom MB, Ekman G, Westergren-Thorsson G, Malmstrom A, Bystrom B, Endresen U, Mlambo N, Norman M, Stabi B, Brauner A: Human cervical ripening, an inflammatory process mediated by cytokines. Mol Hum Reprod 2000, 6:375-381.

7. Olesen AW, Westergaard JG, Olsen J: Perinatal and maternal complications related to postterm delivery: a national register-based study, 1978-1993. Am J Obstet Gynecol 2003, 189:222-227.

8. Lindstrom K, Fernell E, Westgren M: Developmental data in preschool children born after prolonged pregnancy. Acta Paediatr 2005, 94: II 92-II 97.

9. Kistka ZA, Palomar L, Boslaugh SE, DeBaun MR, DeFranco EA, Muglia LJ: Risk for postterm delivery after previous postterm delivery. Am J Obstet Gynecol 2007, I 96(3):24I.el-24I.e6.

10. Norwitz ER, Snegovskikh VV, Caughey AB: Prolonged pregnancy: when should we intervene? Clin Obstet Gynecol 2007, 50:547-557.

II. Hannah ME, Hannah WJ, Hellmann J, Hewson S, Milner R, Willan A: Induction of labor as compared with serial antenatal monitoring in post-term pregnancy. A randomized controlled trial. The Canadian Multicenter Post-term Pregnancy Trial Group. N Engl J Med 1992, 326:1587-1592.

12. Almstrom H, Granstrom L, Ekman G: Serial antenatal monitoring compared with labor induction in post-term pregnancies. Acta Obstet Gynecol Scand 1995, 74:599-603.

13. Wang H, Stjernholm Y, Ekman G, Eriksson H, Sahlin L: Different regulation of oestrogen receptors alpha and beta in the human cervix at term pregnancy. Mol Hum Reprod 200I, 7:293-300.

14. Albanito L, Madeo A, Lappano R, Vivacqua A, Rago V, Carpino A, Oprea TI, Prossnitz ER, Musti AM, Ando S, Maggiolini M: G proteincoupled receptor 30 (GPR30) mediates gene expression changes and growth response to I 7 beta-estradiol and selective GPR30 ligand G-I in ovarian cancer cells. Cancer Res 2007, 67:1859-1866.

15. Prossnitz ER, Arterburn JB, Sklar LA: GPR30: A G protein-coupled receptor for estrogen. Mol Cell Endocrinol 2007, 265266: $138-142$. 
16. Vivacqua A, Bonofiglio D, Recchia AG, Musti AM, Picard D, Ando S, Maggiolini M: The G protein-coupled receptor GPR30 mediates the proliferative effects induced by I 7 beta-estradiol and hydroxytamoxifen in endometrial cancer cells. Mol Endocrinol 2006, 20:63I-646.

17. Sugano T, Narahara H, Nasu K, Arima K, Fujisawa K, Miyakawa I: Effects of platelet-activating factor on cytokine production by human uterine cervical fibroblasts. Mol Hum Reprod 200I, 7:475-48I.

18. Chao W, Olson MS: Platelet-activating factor: receptors and signal transduction. Biochem J 1993, 292 ( Pt 3):617-629.

19. Mutoh $\mathrm{H}, \mathrm{Kume} \mathrm{K}$, Sato $\mathrm{S}$, Kato S, Shimizu T: Positive and negative regulations of human platelet-activating factor receptor transcript 2 (tissue-type) by estrogen and TGF-beta I. Biochem Biophys Res Commun 1994, 205: I I 30- I I 36.

20. Stjernholm-Vladic Y, Stygar D, Mansson C, Masironi B, Akerberg S, Wang $\mathrm{H}$, Ekman-Ordeberg G, Sahlin L: Factors involved in the inflammatory events of cervical ripening in humans. Reprod Biol Endocrinol 2004, 2:74.

21. Predescu D, Ihida K, Predescu S, Palade GE: The vascular distribution of the platelet-activating factor receptor. Eur J Cell Biol 1996, 69:86-98.

22. Stygar D, Wang H, Vladic YS, Ekman G, Eriksson H, Sahlin L Increased level of matrix metalloproteinases 2 and 9 in the ripening process of the human cervix. Biol Reprod 2002, 67:889-894.

23. Nagase $\mathrm{H}$, Woessner JF Jr.: Matrix metalloproteinases. J Biol Chem 1999, 274:2149|-2| 494.

24. Hulboy DL, Rudolph LA, Matrisian LM: Matrix metalloproteinases as mediators of reproductive function. Mol Hum Reprod 1997, 3:27-45.

25. Gotte M, Echtermeyer F: Syndecan-I as a regulator of chemokine function. ScientificWorldjournal 2003, 3:1327-1331.

26. Wu X, Pang ST, Sahlin L, Blanck A, Norstedt G, Flores-Morales A: Gene expression profiling of the effects of castration and estrogen treatment in the rat uterus. Biol Reprod 2003, 69: $1308-13 \mid 7$.

27. Groothuis PG, Dassen HH, Romano A, Punyadeera C: Estrogen and the endometrium: lessons learned from gene expression profiling in rodents and human. Hum Reprod Update 2007, 13:405-417.

28. O'Driscoll K, Foley M, MacDonald D: Active management of labor as an alternative to cesarean section for dystocia. Obstet Gynecol 1984, 63:485-490.

29. Rozen S, Skaletsky H: Primer3 on the WWW for general users and for biologist programmers. Methods Mol Biol 2000, 132:365-386.

30. Wang H, Masironi B, Eriksson H, Sahlin L: A comparative study of estrogen receptors alpha and beta in the rat uterus. Biol Reprod 1999, 61:955-964.

31. Sennstrom MB, Granstrom LM, Lockwood CJ, Omazic B, Johansson $O$, Malmstrom A, Ekman GE: Cervical fetal fibronectin correlates to prostaglandin E2-induced cervical ripening and can be identified in cervical tissue. Am J Obstet Gynecol 1998 I 78:540-545.

32. Stygar D, Westlund $\mathrm{P}$, Eriksson $\mathrm{H}$, Sahlin L: Identification of wild type and variants of oestrogen receptors in polymorphonuclear and mononuclear leucocytes. Clin Endocrinol (Oxf) 2006 64:74-8I.

33. Stygar D, Masironi B, Eriksson H, Sahlin L: Studies on estrogen receptor (ER) \{alpha\} and \{beta\} responses on gene regulation in peripheral blood leukocytes in vivo using selective ER agonists. J Endocrinol 2007, 194:10I-II9.

34. Wang C, Prossnitz ER, Roy SK: Expression of G protein-coupled receptor $\mathbf{3 0}$ in the hamster ovary: differential regulation by gonadotropins and steroid hormones. Endocrinology 2007, 148:4853-4864.

35. Maul H, Shi L, Marx SG, Garfield RE, Saade GR: Local application of platelet-activating factor induces cervical ripening accompanied by infiltration of polymorphonuclear leukocytes in rats. Am J Obstet Gynecol 2002, 187:829-833.

36. Malmstrom E, Sennstrom M, Holmberg A, Frielingsdorf H, Eklund E, Malmstrom L, Tufvesson E, Gomez MF, Westergren-Thorsson G, Ekman-Ordeberg G, Malmstrom A: The importance of fibroblasts in remodelling of the human uterine cervix during pregnancy and parturition. Mol Hum Reprod 2007, I3:333-34I.
37. Timmons BC, Mahendroo MS: Timing of neutrophil activation and expression of proinflammatory markers do not support a role for neutrophils in cervical ripening in the mouse. Biol Reprod 2006, 74:236-245.

38. Yellon SM, Ebner CA, Sugimoto Y: Parturition and recruitment of macrophages in cervix of mice lacking the prostaglandin $F$ receptor. Biol Reprod 2008, 78:438-444.

39. Tornblom SA, Maul H, Klimaviciute A, Garfield RE, Bystrom B, Malmstrom A, Ekman-Ordeberg G: mRNA expression and localization of bNOS, eNOS and iNOS in human cervix at preterm and term labour. Reprod Biol Endocrinol 2005, 3:33.

40. Vaisanen-Tommiska M, Nuutila M, Ylikorkala O: Cervical nitric oxide release in women postterm. Obstet Gynecol 2004, 103:657-662.

4I. Karpuzoglu E, Ahmed SA: Estrogen regulation of nitric oxide and inducible nitric oxide synthase (iNOS) in immune cells: implications for immunity, autoimmune diseases, and apoptosis. Nitric Oxide 2006, I5:177-186.

42. Zhu YP, Hoffman DR, Hwang SB, Miyaura S, Johnston JM: Prolongation of parturition in the pregnant rat following treatment with a platelet activating factor receptor antagonist. Biol Reprod 1991, 44:39-42.

43. Sugano $T$, Nasu $K$, Narahara $H$, Kawano $Y$, Nishida $Y$, Miyakawa I: Platelet-activating factor induces an imbalance between matrix metalloproteinase- $I$ and tissue inhibitor of metalloproteinases-I expression in human uterine cervical fibroblasts. Biol Reprod 2000, 62:540-546.

44. Zhang Q, Seltmann H, Zouboulis CC, Travers JB: Activation of platelet-activating factor receptor in $\mathrm{SZ95}$ sebocytes results in inflammatory cytokine and prostaglandin E2 production. Exp Dermatol 2006, 15:769-774.

45. Osmers R, Rath W, Adelmann-Grill BC, Fittkow C, Kuloczik M, Szeverenyi $M$, Tschesche $H$, Kuhn W: Origin of cervical collagenase during parturition. Am J Obstet Gynecol 1992, I66: | 455- 460.

46. Gotte M: Syndecans in inflammation. Faseb J 2003, I7:575-59I.

47. Marshall LJ, Ramdin LS, Brooks T, PC DP, Shute JK: Plasminogen activator inhibitor-I supports IL-8-mediated neutrophil transendothelial migration by inhibition of the constitutive shedding of endothelial IL-8/heparan sulfate/syndecan-I complexes. J Immunol 2003, I 7 I:2057-2065.

48. Lai TH, King JA, Shih le M, Vlahos NF, Zhao Y: Immunological localization of syndecan-I in human endometrium throughout the menstrual cycle. Fertil Steril 2007, 87:12I-I26.

49. Germeyer A, Klinkert MS, Huppertz AG, Clausmeyer S, Popovici RM, Strowitzki T, von Wolff M: Expression of syndecans, cell-cell interaction regulating heparan sulfate proteoglycans, within the human endometrium and their regulation throughout the menstrual cycle. Fertil Steril 2007, 87:657-663.

50. Feldman AL, Stetler-Stevenson WG, Costouros NG, Knezevic V, Baibakov G, Alexander HR Jr., Lorang D, Hewitt SM, Seo DW, Miller MS, O'Connor S, Libutti SK: Modulation of tumor-host interactions, angiogenesis, and tumor growth by tissue inhibitor of metalloproteinase 2 via a novel mechanism. Cancer Res 2004, 64:448I-4486.

Publish with Bio Med Central and every scientist can read your work free of charge

"BioMed Central will be the most significant development for disseminating the results of biomedical research in our lifetime. "

Sir Paul Nurse, Cancer Research UK

Your research papers will be:

- available free of charge to the entire biomedical community

- peer reviewed and published immediately upon acceptance

- cited in PubMed and archived on PubMed Central

- yours - you keep the copyright
BioMedcentral 